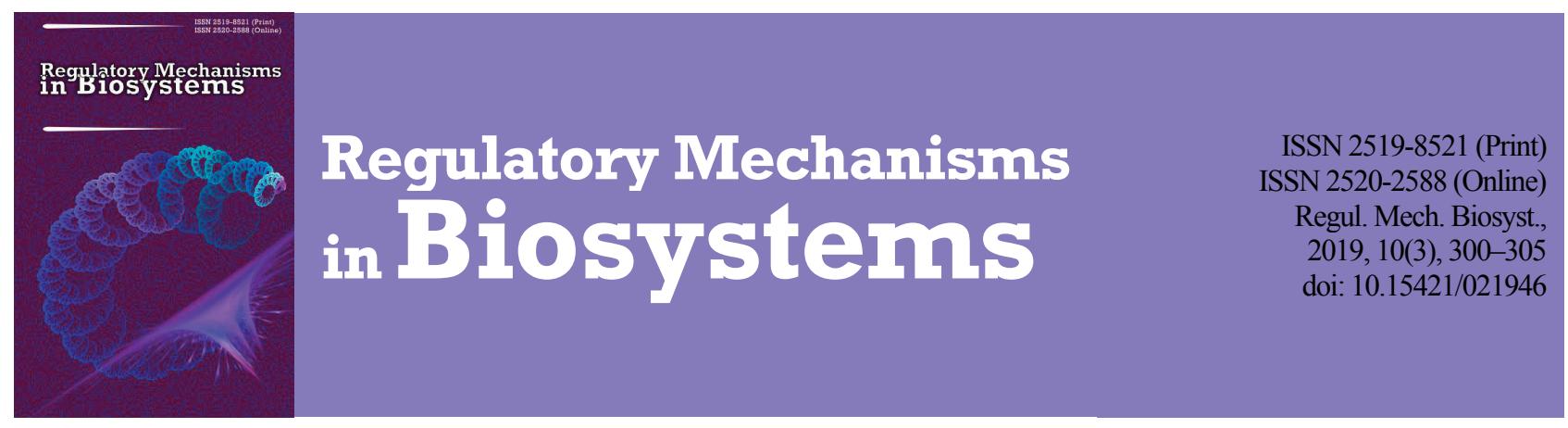

\title{
Breast tumour size as a predictor of hemostatic system status and endothelial function in dogs
}

\author{
D. D. Bely*, M. V. Rublenko**, V. V. Samoyuluk*, I. D. Yevtushenko***, S. N. Maslikov* \\ *Dnipro State Agrarian and Economic University, Dnipro, Ukraine \\ **Bila Tserkva National Agrarian University, Bila Tserkva, Ukraine \\ ***Kharkiv State Veterinary Academy, Kharkiv, Ukraine
}

Article info
Received 29.06.2019
Received in revisedform
04.08.2019
Accepted 05.08.2019
Dnipro State Agrarian
and Economic University,
S. Efremov st., 25,
Dnipro, 49600, Ukraine.
Tel.: +38-050-361-38-30.
E-mail: dmdmbeliy@i.ua
Bila Tserkva National
Agrarian University,
Sobornapl., 8/1,
Bila Tserkva, 09117, Ukraine.
Tel.: +38-050-381-09-77.
E-mail: rublenko@meta.ua
Kharkiv State Veterinary
Academy, Academic st., 1, Mala
Danylivka, 62341, Ukraine.
Tel.: +38-066-298-22-99.
E-mail: aevt76@gmail.com

\section{Introduction}

The relevance of studies of breast tumours in dogs is associated with their widespread use as a model for the study of this disease, due to the similarity of occurrence, clinical signs, in particular the age of development, hormonal etiology, course, as well as factors affecting the prognosis - cell sizes, stages, and invasion of the lymph nodes (Pollan et al., 2009; Abdelmegeed \& Mohammed, 2018).

Studies on the study of breast tumours in dogs, including clinical features, malignant transformation, histogenesis, and epithelial-mesenchymal interactions, provide new information needed to determine their clinical and biological behaviour (Cassali et al., 2012).

Gerry \& Malcolm (2007), based on a retrospective evaluation of the neoplasia process in the breast, identified 4 statistically significant negative prognostic indicators of survival: lack of therapy, the presence of distant metastases including in lymph nodes, and the size of the primary focus, thereby forming clinically important criteria for disease prediction, development of an effective treatment protocol and application for statistical processing and formation of a single base.

Currently, the issue of identifying new biological markers to determine the interaction of hemostasis and mechanisms of neoplasia development and to improve the prevention of thrombotic disorders in this pathology is being actively investigated in human medicine (Falanga \begin{abstract}
tor of hemostatic system status and endothelial function in dogs. Regulatory Mechanisms in Biosystems, 10(3), 300-305.
\end{abstract}
The high level of morbidity of dogs from mammary gland tumours and deficiencies in the pathogenesis give relevance to study of the disorders of the hemostatic system for predicting the neoplasia process. Our research concerned the determination of markers of the hemostatic system and endothelial function at different sizes $(\leq 2,5-7$ and $>10 \mathrm{~cm})$ of benign $(\mathrm{n}=28)$ and maligaccompanied by a 1.24-1.81 times increase in the fibrinogen content in the benign forms and 1.39-2.38 times in malignant against (he results of coagulation tests indicate that the increase in 列 ( 273 times in malignant Regardless of the pathomo

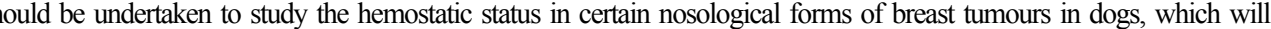

Keywords: neoplasms; hemostasis balance; endothelial function; neoplasia size; hypercoagulation.

et al., 2013). In humans, neoplasia factors of blood coagulation and fibrinolysis, such as tissue factor, thrombin, fibrin, plasminogen activators, plasminogen, and platelets, have been shown to stimulate angiogenesis, thereby contributing to disease progression (Wojtukiewicz et al., 2001). Some researchers have shown that increased coagulopathy is due to the ability of tumour cells to produce procoagulatory/fibrinolytic factors and proinflammatory cytokines to initiate the formation of acute-phase proteins and paraproteins (Caine et al., 2002). At the same time, the degree of hemostatic balance disturbances is influenced by the intensity of the inflammatory response that accompanies the neoplastic process (Marschner et al., 2018). Moreover, haemostasiological dysfunction is often reported in dogs, but such studies are isolated, in most cases descriptive and not systematic. In particular, they have been described for malignant lung tumours in this species. However, against the background of increased fibrinogen content and acceleration of activated partial thromboplastin time in all cases, metastasis was significantly higher in these markers compared to locally invasive and non-invasive lesions (Andreasen et al., 2012).

Despite established hemostatic abnormalities in breast carcinoma in dogs, higher levels of coagulopathy are likely in patients with stage III and IV neoplasia, as well as in the presence of metastases, significant areas of necrosis, and pronounced inflammatory response (Stockhaus et al., 1999). Disseminated intravascular coagulation syndrome is not 
"typical" in all cases and the degree of the disease correlates with hypercoagulation (Vilar Saavedra et al., 2011), due to which hyper-, normal and hypocoagulative conditions are possible for thrombosis (Bauer \& Moritz, 2013). According to Kristensen et al. (2008) in malignant neoplasms of the breast, the state of hypercoagulation is diagnosed in $50 \%$ of patients, whereas hypocoagulation, which is caused by metastasis, is diagnosed in $17 \%$ of dogs.

In human medicine it has been proved that the participation of hemostatic proteins in the pathogenesis and progression of neoplasia is not limited to their role in the mechanisms of thrombus formation, they are actively involved in the biology of tumours, and therefore have a potential predictive value. In particular, fibrinogen, fibrin and their breakdown products cause pro-inflammatory action, impaired endothelial function with platelet activation, contribute to the development of the vascular system of the tumour by stimulating proliferation, migration, and differentiation of endothelial cells, as well as metastasis (Chapin \& Hajjar, 2015; Kolodziejczyk-Czepas et al., 2017).

The dynamics of thrombin formation, which plays a key role in the coagulation cascade, is highly dependent on specific factors involved in blood clotting (Adesanya et al., 2016) and correlates with high levels of tissue factor malignancy in malignancies, especially with disease progression (Gruber et al., 2016). A prognostic indicator of the neoplasia process in dogs that characterizes its progression is the degree of expression of oxidative stress by serum malondialdehyde, which is associated with tissue damage (Macotpet et al., 2013). Matrix metalloproteinases and their tissue inhibitors, which are involved in the progression of the disease, providing structural and vascular support for tumour growth, are considered biological markers for predicting the development of breast tumours (Aresu et al., 2011).

Thus, markers of hemostasis and endothelial function are key factors that determine the procoagulatory profile of a tumour, which is important for addressing directed antithrombotic prophylaxis and therapy (Docampo et al., 2011; Marchetti et al., 2012). At the same time, despite the available publications on hemostatic disorders in tumours in dogs, only the fact of the development of hypercoagulation has been confirmed, while the role of the hemostasis system in the pathogenesis of neoplasmic lesions has not been established. This situation is related to the complexity and versatility of the mechanisms of development of tumours, including the involvement of coagulation factors and blood proteolysis. Therefore, studies of the hemostasis system for breast neoplasia in dogs remain relevant, given the possibility of using their results to predict the course of the disease, develop effective treatment protocols, and prevent recurrence and metastasis.

Taking into account the established patterns of violation of hemostatic balance, endothelial function and the presence of other paraneoplastic syndromes in dogs with neoplasms of the breast (Bely et al., 2018), we studied the characteristics of their changes at different sizes of tumour foci.

The purpose of the study is to determine the features of disorders of the hemostasis system and endothelial function in different sizes of breast tumours in dogs and their significance in predicting the course of the disease.

\section{Materials and methods}

The studies were conducted in accordance with the requirements of the European Convention on the Protection of Vertebrate Animals (Strasbourg, 1986) and the Law of Ukraine "On the Protection of Animals Against Cruelty" (2006), which was confirmed by the conclusion of the Bioethics Commission of the Dnipro State Agrarian and Economic University. Clinical studies were performed under the conditions of the Department of Surgery and Obstetrics of Farm Animals, pathomorphological - the Department of Normal and Pathological Anatomy of Animals of the Dnipro State Agrarian and Economic University, determination of hemostatic and biochemical parameters - the Department of Surgery and Diseases of Small Pets, Bilotserkiv National Agrarian University during 2016-2018.

After the anamnesis was collected, the features of the clinical course of the neoplasia process were determined, the markers of the hemos- tasis system and the pathomorphological structure of breast tumours were investigated, taking into account the size of the lesion. The patients were divided into groups according to the size of the neoplasms (up to $2 \mathrm{~cm}, 5-7 \mathrm{~cm}$, and $10 \mathrm{~cm}$ and more) and histological type, the number of animals with benign forms was 4, 15 and 9, and malignant - 5, 12 and 10 dogs, respectively.

Benign neoplasia was presented by fibroadenomas, malignant carcinomas (simple and complex) of 1-3 stages, without metastases in regional lymph nodes and distant organs and tissues, in particular, lungs.

The study of coagulation potential was based on the determination of fibrinogen concentration (Belicer et al., 1997), soluble fibrin (Vareckaja et al., 1992), duration of activated partial thromboplastin (set of reagents from Simko LTD, Lviv) and prothrombin time (Quick, 1974).

The study of the state of the fibrinolysis system (by area of lysis $\left(\mathrm{mm}^{2}\right)$ of the fibrinous blood clot), which included determination of the total fibrinolytic activity of blood plasma, plasmin activity and activity of tissue plasminogen activator was performed by the method of fibrin plates according to Astrup \& Millertz (1952). The inhibitory potential was determined by the plasma content of the $\alpha_{1}$-inhibitor of proteinases and $\alpha_{2}$-macroglobulin (Veremeenko et al., 1978).

Among biochemical parameters, we investigated the content of total protein by biuretic reaction, albumin - by reaction with bromcresol green, ceruloplasmin - by the method of Ravin, malonic dialdehyde by the method of Andreeva et al. (1988), nitric oxide - Golikov (2004). Pathomorphological verification of the tumours of the mammary gland was performed by microscopy of thin histological sections stained with hematoxylin and eosin according to the conventional method (Goral's'kij, 2015).

Statistical processing of the results was performed using Statistica 10 (StatSoft Inc., USA, 2011). A Bonferroni-corrected ANOVA was used to determine the difference between the samples.

\section{Results}

The content of fibrinogen at different sizes of breast tumours in female dogs had certain patterns (Table 1). For any pathomorphic type of neoplasia 5-7 cm in size, its concentration did not go beyond the parameters of clinically healthy dogs. In benign neoplasms, the level of fibrinogen in patients with small tumours (up to $2 \mathrm{~cm}$ ) exceeded the physiological norm by 1.24 times $(\mathrm{P}<0.05)$, giant (more than $10 \mathrm{~cm})-$ by 1.81 times $(\mathrm{P}<0.001)$, and in malignant neoplasia - by $1.39(\mathrm{P}<$ $0.01)$ and $2.39(\mathrm{P}<0.001)$ times, respectively. With increase in the size of the neoplasmic lesion from 2 to $5-7 \mathrm{~cm}$, its concentration did not change significantly. At the same time, the content of fibrinogen increased by 1.69 times $(\mathrm{P}<0.001)$ and malignant 1.95 times $(\mathrm{P}<0.01)$ as the process progressed and increased from 5-7 to $10 \mathrm{~cm}$ or more.

\section{Table 1}

Fibrinogen and soluble fibrin content depending on the size of breast neoplasia $(x \pm S E)$

\begin{tabular}{lcrcc}
\hline $\begin{array}{c}\text { Pathomorphological } \\
\text { type of neoplasia }\end{array}$ & $\begin{array}{c}\text { Size of } \\
\text { tumours, } \\
\mathrm{cm}\end{array}$ & $\mathrm{n}$ & Fibrinogen, g/L & $\begin{array}{c}\text { Soluble fibrin, } \\
\mathrm{mg} / 100 \mathrm{~mL}\end{array}$ \\
\hline $\begin{array}{l}\text { Clinically healthy } \\
\text { animals }\end{array}$ & - & 17 & $2.07 \pm 0.16$ & $0.08 \pm 0.03$ \\
\hline \multirow{4}{*}{ Benign } & $\leq 2$ & 4 & $2.56 \pm 0.07^{*}$ & $27.35 \pm 2.21^{* * *}$ \\
& $5-7$ & 15 & $2.21 \pm 0.10$ & $25.29 \pm 1.86^{* * *}$ \\
& $\geq 10$ & 9 & $3.74 \pm 0.15^{* * * . . \bullet \circ \circ}$ & $35.21 \pm 1.34^{* * * \bullet \bullet}$ \\
\hline \multirow{3}{*}{ Malignant } & $\leq 2$ & 5 & $2.88 \pm 0.17^{* *}$ & $36.36 \pm 3.09^{* * *}$ \\
& $5-7$ & 12 & $2.53 \pm 0.13$ & $48.22 \pm 2.15^{* * *}$ \\
& $\geq 10$ & 10 & $4.94 \pm 0.34^{* * * * \bullet \circ}$ & $55.89 \pm 2.11^{* * * \bullet}$ \\
\hline
\end{tabular}

Note: data are valid at $* .{ }^{\circ}-\mathrm{P}<0.05 ; * * . .{ }^{\circ}-\mathrm{P}<0.01 ; * * * . .{ }^{\circ}-\mathrm{P}<0.001$, relative to: ${ }^{*}$ - clinically healthy animals (control), $\bullet$ - tumours $\leq 2 \mathrm{~cm}$ in size, ${ }^{\circ}-$ neoplasms of $5-7 \mathrm{~cm}$ in size by comparison with the Bonferroni-corrected ANOVA.

The increase in the size of breast tumours was accompanied by an increase in soluble fibrin accumulation $(\mathrm{P}<0.001)$ in all groups. In benign neoplasms, its content was found to increase in patients with giant tumours $(\geq 10 \mathrm{~cm})$, relatively small $(\leq 2 \mathrm{~cm})-1.29$ times $(\mathrm{P}<0.05)$, medium $(5-7 \mathrm{~cm})-1.39$ times $(\mathrm{P}<0.01)$. The content of soluble fibrin in malignant tumours of size 5-7 cm and more than $10 \mathrm{~cm}$ exceeded the 
values of dogs with neoplasia by up to $2 \mathrm{~cm}$, by $1.33(\mathrm{P}<0.05)$ and $1.54(\mathrm{P}<0.01)$ times, respectively, against the background of no significant difference between these groups.

Against the background of excessive accumulation of fibrin and soluble fibrin, there was an increased consumption of plasma hemostasis factors, which was accompanied by activation of internal and external blood coagulation pathways and was reflected in the dynamics of activated partial thromboplastin and prothrombin tests (Table 2).

Activated partial thromboplastin time for benign tumours of small size (up to $2 \mathrm{~cm}$ ) was accelerated 1.46 times $(\mathrm{P}<0.01$ ), with an increase in their magnitude their parameters increased, in patients with neoplasms 5-7 cm they were within the physiological norm, and in those with tumours over $10 \mathrm{~cm}$ they lengthened 1.23 times $(\mathrm{P}<0.01)$, indicating a deepening of the coagulation factor deficiency. In this case, relatively small neoplasia activated partial thromboplastin time was slowed 1.39 times $(\mathrm{P}<0.05)$ for values of 5-7 cm and already 1.80 times $(\mathrm{P}<$ 0.001 ) for tumours over $10 \mathrm{~cm}$ against the 1.30 times difference between these groups $(\mathrm{P}<0.05)$. At the same time, for any size of malignant tumours, the activated partial thromboplastin time was delayed $1.52-1.65$ times $(\mathrm{P}<0.001)$ against the background of no significant difference between the groups.

A similar situation was observed in dogs with benign neoplasms regarding prothrombin time. If for tumours up to $2 \mathrm{~cm}$, it corresponded to the index of clinically healthy animals, then with the increase of their size up to 5-7 cm, it extended 2.25 times $(\mathrm{P}<0.01)$, and for tumours more than $10 \mathrm{~cm}-2.92$ times $(\mathrm{P}<0.001)$, compared to clinically healthy bitches -2.61 and 3.38 times $(\mathrm{P}<0.001)$, respectively, for the difference between these groups in 1.30 times $(\mathrm{P}<0.05)$.

In malignant neoplasms, the progression of the process was accompanied by prolongation of prothrombin time that exceeded that of clinically healthy dogs for tumours up to $2 \mathrm{~cm}-1.82$ times $(\mathrm{P}<0.01), 5$ $7 \mathrm{~cm}-4.36$ times $(\mathrm{P}<0.001)$, tumours over $10 \mathrm{~cm}-5.35$ times $(\mathrm{P}<$ 0.001). At the same time, compared to small neoplasia (up to $2 \mathrm{~cm}$ ), it was larger $(\mathrm{P}<0.001)$ for tumours of $5-7 \mathrm{~cm}$ by 2.40 times, more than $10 \mathrm{~cm}-2.94$ times, against the background of no significant difference between these groups.

\section{Table 2}

Indicators of coagulation tests for different sizes of breast tumours in $\operatorname{dogs}(\mathrm{x} \pm \mathrm{SE})$

\begin{tabular}{lcrcc}
\hline $\begin{array}{c}\text { Pathomorphological } \\
\text { type of neoplasia }\end{array}$ & $\begin{array}{c}\text { Size of } \\
\text { tumours, } \\
\mathrm{cm}\end{array}$ & $\mathrm{n}$ & $\begin{array}{c}\text { Activated partial } \\
\text { thromboplastin } \\
\text { time, } \mathrm{s}\end{array}$ & $\begin{array}{c}\text { Prothrombin } \\
\text { time, } \mathrm{s}\end{array}$ \\
\hline Clinically healthy animals & - & 17 & $45.7 \pm 1.1$ & $8.9 \pm 0.7$ \\
\hline \multirow{3}{*}{ Benign } & $\leq 2$ & 4 & $31.2 \pm 2.9^{* *}$ & $10.3 \pm 1.4$ \\
& $5-7$ & 15 & $43.3 \pm 3.2^{*}$ & $23.2 \pm 1.6^{* * * . \bullet}$ \\
& $\geq 10$ & 9 & $56.2 \pm 1.6^{* * . . .}$ & $30.1 \pm 1.5^{* * * . . \circ}$ \\
\hline \multirow{3}{*}{ Malignant } & $\leq 2$ & 5 & $69.5 \pm 2.2^{* * *}$ & $16.2 \pm 1.1^{* *}$ \\
& $5-7$ & 12 & $70.9 \pm 3.4^{* * *}$ & $38.8 \pm 2.2^{* * * . .}$ \\
& $\geq 10$ & 10 & $75.2 \pm 2.9^{* * * *}$ & $47.6 \pm 2.7^{* * * . .}$ \\
\hline
\end{tabular}

Note: see Table 1.

Thus, for breast tumours, the activation of the coagulation unit of the hemostatic system occurs mainly through an external mechanism stimulated by a tissue factor, the formation of which occurs both directly by neoplastic cells and as a result of tissue damage. In this case, the violation of fibrinogen metabolism and the deepening of the hypercoagulable state, in particular due to the deficiency of plasma coagulation factors, with an increase in the size of tumours, indicate the formation of a stage of coagulopathy of consumption of disseminated intravascular coagulation syndrome.

At the same time, the analysis of fibrinolytic activity at different sizes of breast tumours in dogs allowed us to establish certain regularities (Table 3). In particular, despite the benign tumours, the dynamics of suppression of total fibrinolytic activity did not allow us to detect a significant difference between its parameters in the group of neoplasms of about $2 \mathrm{~cm}$ and more than $10 \mathrm{~cm}$, regardless of the size of the tumour, it was significantly lower than in clinically healthy animals 1.20 1.33 times $(\mathrm{P}<0.05 ; \mathrm{P}<0.01)$. In malignant neoplasia, their size did not affect the level of total fibrinolytic activity - in all cases, its suppression was recorded, compared with clinically healthy animals. At the same time, it was significantly lower $(\mathrm{P}<0.05)$ for tumours over $10 \mathrm{~cm}$ relative to the indicator for small (up to $2 \mathrm{~cm}$ ) tumours.

At the same time, plasmin activity, compared to the index for clinically healthy dogs, was suppressed by -1.38 times $(\mathrm{P}<0.01)$ for benign tumours more than $10 \mathrm{~cm}$ while for values up to $2 \mathrm{~cm}$ and $5-7 \mathrm{~cm}$ it fluctuated within the physiological norm. In patients with malignant neoplasia up to $7 \mathrm{~cm}$, its index was not significantly different from clinically healthy animals, and with malignant neoplasia over $10 \mathrm{~cm}-\mathrm{a}$ 1.33 times $(\mathrm{P}<0.05)$ decrease was registered against the background of no significant difference between groups.

At the same time, inhibition of tissue plasminogen activator level in malignant neoplasms was found to be $1.62-2.03$ times $(\mathrm{P}<0.01)$ without significant difference, depending on their size. For benign neoplasia, its activity was reduced only in patients with neoplasia of 5-7 cm in size.

That is, the reduction of total fibrinolytic activity occurred mainly due to the tissue plasminogen activator, which reflects the degree of neoplasm aggression.

Table 3

The state of fibrinolysis in various sizes of breast neoplasia in $\operatorname{dogs}(\mathrm{x} \pm \mathrm{SE})$

\begin{tabular}{lcrccc}
\hline $\begin{array}{c}\text { Pathomorphological } \\
\text { type of neoplasia }\end{array}$ & $\begin{array}{c}\text { Size of } \\
\text { tumours, } \\
\mathrm{cm}\end{array}$ & $\mathrm{n}$ & $\begin{array}{c}\text { Total fib- } \\
\text { rinolytic } \\
\text { activity, } \mathrm{mm}^{2}\end{array}$ & $\begin{array}{c}\text { Plasma } \\
\text { activator, } \\
\mathrm{mm}^{2}\end{array}$ & $\begin{array}{c}\text { Tissue plas- } \\
\text { minogen acti- } \\
\text { vator, mm }\end{array}$ \\
\hline $\begin{array}{l}\text { Clinically } \\
\text { healthy animals }\end{array}$ & - & 17 & $603 \pm 23$ & $285 \pm 11$ & $321 \pm 23$ \\
\hline \multirow{3}{*}{ Benign } & $\leq 2$ & 4 & $503 \pm 24^{*}$ & $244 \pm 16$ & $259 \pm 13$ \\
& $5-7$ & 15 & $495 \pm 29^{*}$ & $255 \pm 22$ & $240 \pm 12^{*}$ \\
& $\geq 10$ & 9 & $452 \pm 24^{* *}$ & $206 \pm 18^{* *}$ & $246 \pm 19$ \\
\hline \multirow{3}{*}{ Malignant } & $\leq 2$ & 5 & $458 \pm 17^{* *}$ & $261 \pm 13$ & $198 \pm 17^{* *}$ \\
& $5-7$ & 12 & $414 \pm 15^{* *}$ & $256 \pm 21$ & $158 \pm 23^{* *}$ \\
& $\geq 10$ & 10 & $391 \pm 19^{* * *}$ & $215 \pm 23^{*}$ & $176 \pm 17^{* *}$ \\
\hline
\end{tabular}

Note: see Table 1

The increase in coagulation potential, as an indicator of paraneoplasia syndrome, was accompanied by activation of the proteolytic unit of blood (Table 4). In benign neoplasia, the level of the $\alpha_{1}$-inhibitor of proteinases, compared with clinically healthy animals, regardless of size, was increased 1.11-1.20 times $(\mathrm{P}<0.05)$ without significant difference between the groups.

In the case of malignant neoplasms of giant size ( $\geq 10 \mathrm{~cm})$, its activity decreased by 1.15 times $(\mathrm{P}<0.05)$, against a 1.11 times $(\mathrm{P}<0.05)$ increase in patients with average size tumours $(5-7 \mathrm{~cm})$. A significant difference in the content of the $\alpha_{1}$-inhibitor of proteinases in the group of 5-7 $\mathrm{cm}$ was established, compared with values up to $2 \mathrm{~cm}$ and more than $10 \mathrm{~cm}-$ by $1.21(\mathrm{P}<0.05)$ and $1.28(\mathrm{P}<0.01)$ times, respectively.

Table 4

Activity of proteolysis inhibitors for breast tumours in $\operatorname{dogs}(\mathrm{x} \pm \mathrm{SE})$

\begin{tabular}{lcrcc}
\hline $\begin{array}{c}\text { Pathomorphological type } \\
\text { of neoplasia }\end{array}$ & $\begin{array}{c}\text { Size of } \\
\text { tumours, } \\
\mathrm{cm}\end{array}$ & $\mathrm{n}$ & $\begin{array}{c}\alpha_{1} \text { - proteinase } \\
\text { inhibitor, } \\
\mu \mathrm{mol} / \mathrm{L}\end{array}$ & $\begin{array}{c}\alpha_{2} \text {-macroglobulin, } \\
\mathrm{g} / \mathrm{L}\end{array}$ \\
\hline Clinically healthy animals & - & 17 & $77.6 \pm 1.5$ & $1.48 \pm 0.07$ \\
\hline \multirow{3}{*}{ Benign } & $\leq 2$ & 4 & $88.9 \pm 2.2^{*}$ & $1.62 \pm 0.02$ \\
& $5-7$ & 15 & $86.5 \pm 2.2^{*}$ & $1.76 \pm 0.04^{*}$ \\
& $\geq 10$ & 9 & $93.5 \pm 3.6^{*}$ & $1.83 \pm 0.07_{\bullet}$ \\
\hline \multirow{3}{*}{ Malignant } & $\leq 2$ & 5 & $71.5 \pm 2.2$ & $1.85 \pm 0.04^{*}$ \\
& $5-7$ & 12 & $86.3 \pm 1.7^{*}$ & $2.14 \pm 0.03^{*} *$ \\
& $\geq 10$ & 10 & $67.2 \pm 2.1^{* \circ \circ}$ & $3.01 \pm 0.07 * * *_{\bullet \bullet}$ \\
\hline
\end{tabular}

Note: see Table 1.

At the same time, the content of $\alpha_{2}$-macroglobulin in animals with benign breast tumours up to $2 \mathrm{~cm}$ in size was at the level of clinically healthy animals, while with 5-7 cm tumours it increased $(\mathrm{P}<0.05)$ 1.19 times, and with tumours over $10 \mathrm{~cm}-1.24$ times. Compared to small neoplasms $(\leq 2 \mathrm{~cm})$, as the neoplasia process progressed, its activity increased 1.13 times $(\mathrm{P}<0.05)$. In the case of malignant types of breast tumours, the level of $\alpha_{2}$-macroglobulin increased relative to the index of clinically healthy dogs by $1.25-2.03$ times $(\mathrm{P}<0.05 ; \mathrm{P}<0.001)$. With relatively small tumours its activity increased by 1.16 times $(\mathrm{P}<$ 0.01 ) for tumours $5-7 \mathrm{~cm}$ in size), for tumours over $10 \mathrm{~cm}$ by 1.63 
times $(\mathrm{P}<0.001)$, between these groups - by 1.41 times $(\mathrm{P}<0.001)$. In most females dog with neoplasms of the breast, regardless of their histomorphogenesis, there is a significant activation of lipid peroxidation, as evidence of a violation of the antioxidant status of the body and the formation of endotoxicosis (Table 5). The increase of accumulation in the serum of malondialdehyde is shown by the increase of oxidative stress and endotoxicosis in the case of growth and progression of the neoplasia: small sizes (up to $2 \mathrm{~cm})$ - by 1.29 times $(\mathrm{P}<0.05)$, average $(5-7 \mathrm{~cm})-1.41$ times $(\mathrm{P}<0.01)$, giant -1.70 times $(\mathrm{P}<0.001)$. In malignant neoplasms, a similar dynamic was reported, with significantly higher content in the blood ( $\mathrm{P}<0.001)$, compared to clinically healthy animals, at $1.58,2.22$ and 2.73 times, respectively.

Malonic dialdehyde content in large (more than $10 \mathrm{~cm}$ ) benign tumours exceeded the rates in patients with small $(\leq 2 \mathrm{~cm})$ foci by 1.32 times $(\mathrm{P}<0.01)$, median $(5-7 \mathrm{~cm})$ by 1.21 times $(\mathrm{P}<0.05)$. For malignant types, the concentration of malondialdehyde increased by 1.40 1.73 times with increasing magnitude $(\mathrm{P}<0.01, \mathrm{P}<0.001)$.

At the same time, the level of endothelial function of nitric oxide relative to the index of clinically healthy animals in patients with benign small and medium $(5-7 \mathrm{~cm})$ tumours did not differ significantly from it, and in animals with large tumours $(\geq 10 \mathrm{~cm})$ - exceeded it by 1.27 times $(\mathrm{P}<0.05)$. The increase in the size of the neoplasm was accompanied by an increase in the production of nitric oxide and its excess concentration in the blood. In particular, its content for neoplasia of 5-7 cm and more than $10 \mathrm{~cm}$ exceeded the corresponding values for tumours up to $2 \mathrm{~cm}$ by $1.22(\mathrm{P}<0.05)$ and $1.42(\mathrm{P}<0.01)$ times, respectively, against the background of the difference between these groups of 1.17 times $(\mathrm{P}<0.05)$.

In malignant neoplasms, the content of nitric oxide exceeded the physiological norm against the tendency to increase as the process progresses. In particular, tumour growth of up to 5-7 $\mathrm{cm}$ was characterized by an increase in the level of nitric oxide by 1.34 times $(\mathrm{P}<0.01)$, up to $10 \mathrm{~cm}$ and more by 1.50 times $(\mathrm{P}<0.001)$, with a difference of 1.12 times $(\mathrm{P}<0.05)$.

The concentration of ceruloplasmin in benign neoplasia was lower than in clinically healthy dogs by $1.10-1.32$ times $(\mathrm{P}<0.05, \mathrm{P}<0.001)$. At the same time, its concentration in tumours of $5-7 \mathrm{~cm}$ and more than $10 \mathrm{~cm}$ was higher than in those of up to $2 \mathrm{~cm}$ by $1.15-1.20$ times $(\mathrm{P}<$ $0.05, \mathrm{P}<0.01)$ against the background of no significant difference between these groups.

In female dogs with malignant tumors up to $2 \mathrm{~cm}$, the content of ceruloplasmin was below the physiological norm by 1.26 times $(\mathrm{P}<0.01)$, and in bitches with malignant tumours of 5-7 cm and more than $10 \mathrm{~cm}$ it did not differ significantly from the norm. At the same time, the indices of these groups were 1.28-1.33 times higher than for small neoplasia $(\leq 2)(\mathrm{P}<0.01)$. That is, the presented results confirm the decrease of the antioxidant status of the organism due to the increase of lipid peroxidation processes, which increase with the size of the neoplasms, but primarily due to their malignant genesis.

\section{Table 5}

Nitric oxide content and antioxidant status in various breast tumours $(\mathrm{x} \pm \mathrm{SE})$

\begin{tabular}{|c|c|c|c|c|c|}
\hline $\begin{array}{l}\text { Pathomorpho- } \\
\text { logical type } \\
\text { of neoplasia }\end{array}$ & $\begin{array}{l}\text { Size of } \\
\text { tumours, } \\
\mathrm{cm}\end{array}$ & $\mathrm{n}$ & $\begin{array}{c}\text { Malonic } \\
\text { dialdehyde, } \\
\mu \mathrm{mol} / \mathrm{L}\end{array}$ & $\begin{array}{c}\text { Nitric } \\
\text { oxide, } \\
\mu \mathrm{mol} / \mathrm{L}\end{array}$ & $\begin{array}{l}\text { Cerulo- } \\
\text { plasmin, } \\
\text { mg/L }\end{array}$ \\
\hline $\begin{array}{l}\text { Clinically } \\
\text { healthy animals }\end{array}$ & - & 17 & $9.6 \pm 0.5$ & $30.9 \pm 1.3$ & $28.2 \pm 0.3$ \\
\hline \multirow{3}{*}{ Benign } & $\leq 2$ & 4 & $12.4 \pm 0.5^{*}$ & $27.4 \pm 0.8$ & $21.3 \pm 0.4^{* * *}$ \\
\hline & $\overline{5}-7$ & 15 & $13.5 \pm 0.3^{* *}$ & $33.5 \pm 1.1 \bullet$ & $25.6 \pm 0.4 * \bullet$ \\
\hline & $\geq 10$ & 9 & $16.3 \pm 0.3^{* * * *_{. \circ} \circ}$ & $39.1 \pm 1.5^{* . \bullet} \circ$ & $24.4 \pm 0.3 *_{\bullet}$ \\
\hline \multirow{3}{*}{ Malignant } & $\leq 2$ & 5 & $15.2 \pm 0.3 * * *$ & $35.2 \pm 1.1$ & $22.4 \pm 0.7^{* *}$ \\
\hline & $5-7$ & 12 & $21.3 \pm 0.9^{* * *}$ & $41.4 \pm 1.3 * *$ & $29.8 \pm 0.7 \bullet \bullet$ \\
\hline & $\geq 10$ & 10 & $26.2 \pm 1.1^{* * * * 0.0}{ }^{\circ}$ & $46.3 \pm 1.3^{* * * . \bullet \circ}$ & $28.7 \pm 0.6 \bullet \bullet$ \\
\hline
\end{tabular}

Note: see Table 1.

In dogs with breast neoplasia, there was hypoproteinemia, which, however, was not accompanied in most cases by significant changes in serum albumin concentration (Table 6). Animals with benign tumours had hypoproteinemia, regardless of their size. However, for small size neoplasia $(\leq 2 \mathrm{~cm})$, the total protein content was below the index of clinically healthy animals $(64.2 \mathrm{~g} / \mathrm{L}) 1.23$ times $(\mathrm{P}<0.05)$, whereas for large sizes $(\geq 10 \mathrm{~cm})$ it was already 1.47 times lower $(\mathrm{P}<0.01)$. In ma- lignant tumours up to $7 \mathrm{~cm}$ in size, the level of total protein was not significantly different from clinically healthy animals, but a further increase in tumour size was accompanied by a decrease in its concentration by 1.60 times $(\mathrm{P}<0.01)$.

\section{Table 6}

Content of total protein and albumin in the serum of dogs in different sizes of breast tumours $(x \pm \mathrm{SE})$

\begin{tabular}{lcrcc}
\hline $\begin{array}{c}\text { Pathomorphological } \\
\text { type of neoplasia }\end{array}$ & $\begin{array}{c}\text { Size of } \\
\text { tumours, cm }\end{array}$ & $\mathrm{n}$ & $\begin{array}{c}\text { Total protein, } \\
\mathrm{g} / \mathrm{L}\end{array}$ & $\begin{array}{c}\text { Albumin, } \\
\mathrm{g} / \mathrm{L}\end{array}$ \\
\hline Clinically healthy animals & - & 17 & $64.2 \pm 3.0$ & $33.2 \pm 1.8$ \\
\hline \multirow{3}{*}{ Benign } & $\leq 2$ & 4 & $52.1 \pm 1.9^{*}$ & $29.8 \pm 2.8$ \\
& $5-7$ & 15 & $52.5 \pm 3.4$ & $27.3 \pm 2.5$ \\
& $\geq 10$ & 9 & $43.6 \pm 1.9^{* *} \bullet$ & $25.4 \pm 2.6$ \\
\hline \multirow{3}{*}{ Malignant } & $\leq 2$ & 5 & $55.6 \pm 3.5$ & $28.6 \pm 3.1$ \\
& $5-7$ & 12 & $60.4 \pm 3.9$ & $31.7 \pm 1.6$ \\
& $\geq 10$ & 10 & $40.2 \pm 1.9^{* * . \bullet} \circ$ & $26.6 \pm 3.8$ \\
\hline
\end{tabular}

Note: see Table 1.

Total protein content in animals with neoplasms greater than $10 \mathrm{~cm}$ was significantly lower than in patients with small tumours: in benign tumours 1.19 times $(\mathrm{P}<0.05)$, malignant -1.38 times $(\mathrm{P}<0.01)$, and with medium sized tumours in the first case it significantly did not change, in the second it decreased 1.5 times $(\mathrm{P}<0.01)$. The serum albumin concentration of patients with breast tumours did not go beyond that of the clinically healthy dogs and did not depend on tumour size.

Thus, an increase in the size of breast tumors in dogs is accompanied by an increase in blood coagulation potential against the background of a worsening of coagulation deficits, which indicates an increase in neoplasia aggression and a deterioration in prognosis. The level of markers of the hemostatic system and endothelial function correlates with the magnitude of the tumours and can be used to predict the course of the disease and to evaluate the effectiveness of treatment interventions.

\section{Discussion}

Cancer-related thrombosis remains a major complication in cancer treatment and confirms the relationship of the hemostasis system with cancer biology (Ruf et al., 2016). Thrombosis is often diagnosed as the first symptom in patients with tumours, and the clinical management of hypercoagulation in cancer patients remains difficult due to the concomitant changes in the factors that predispose the risk of severe bleeding. Therefore, research aimed at better understanding of the interaction of the hemostasis system with the biology of neoplasms remains a priority (Graf \& Ruf, 2018).

At the same time, given that there is a significant degree of similarity between certain breast tumours in dogs and humans (Al-Mansour et al., 2018), further studies are needed to carefully evaluate the diagnostic and biological role of markers, and to clarify whether dogs provide a suitable model for the study of human breast cancer (Burrai et al., 2015). In particular, it has been shown that the proteins of the hemostatic system affect various stages of metastasis, angiogenesis and proteolytic mechanisms (Sierko \& Wojtukiewicz, 2007; Lima \& Monteiro, 2013), and malignancy is associated with changes in the hemostatic system that occur in the form of thromboembolic disorders (Wojtukiewicz et al., 2004), which is reflected in the results of our studies, in particular, increased hypercoagulation with increase in the size of tumours in bitches.

Evaluation of hemostatic markers, which reflect the activation status of the internal and external blood coagulation pathways, is of some importance in the diagnosis, treatment, and prognosis of its efficacy in bitches suffering from mammary tumours. In this case, Kaszak et al. (2018) believe that biological markers of cancer have not been well studied, although their identification is very important for early diagnosis of tumours and for evaluating disease progression and the response to chemotherapy. First of all, this concerns such indicators as the level of fibrinogen, the degree of accumulation in the blood of soluble fibrin, consumption of plasma factors of hemostasis, duration of activated partial and prothrombin time, total fibrinolytic and plasmin activity, as well as the concentration of ceruloplasmin and other biological markers. 
Future studies, both prospective and retrospective, will help determine their prognostic value in veterinary oncology (Peña et al., 2014).

Based on breast carcinoma, the prognostic significance of the clinical stage, one of the indicators of which is the magnitude of neoplasia, and histological structure have been proved (Cerovšek et al., 2013). At the same time, the question of the relationship between breast neoplasms and their aggressiveness is under discussion (Ferreira et al., 2009), which is associated with the use of clinical criteria in most cases, whereas hemostatic disorders in different tumour sizes have not been studied. In particular, despite the widespread belief that malignancy in dogs is benign in $50 \%$ of cases, there has recently been a growing number of reports of malignancy with predominant localization in inguinal mammary glands and $>3 \mathrm{~cm}$ in size (Ariyarathna et al., 2018).

The results obtained are consistent with those of other authors, according to which an increase in the degree of TNM, which is characterized by an increase in the size of lesions, invasion into the surrounding tissues and the development of metastases, worsening of the clinical prognosis, which is reflected in a decrease in patient survival. However, no pathomorphological type dependence has been established within malignant and benign tumours (Yamagami et al., 1996; Benavente et al., 2016). In particular, the survival of two years is significantly associated with clinical stage, tumour size, metastasis to regional lymph nodes or distant tissues and organs, and histological classification. Tumours larger than $5 \mathrm{~cm}$ in diameter, detected 6 months before surgery had a high incidence of lymph node metastasis (Chang et al., 2005).

The significance of clinical evaluation of breast tumours is confirmed by the results of Goldschmid et al. (2011) and Soares et al. (2017), according to which the survival rate of dogs with stage III cancer was significantly lower compared to stage I and stage II against the background of absence of differences between stage II and stage III, in which the prognosis is unfavourable. Dogs with stage III non-differentiated carcinomas were at increased risk of death compared with differentiated stage I and stage II cancers.

The established dependence of the level of thrombotic disorders on the magnitude of breast tumours in dogs agrees with the proven increase in the frequency of involvement in the process of lymph nodes, blood vessels and skin as it grows in size (Orang et al., 2013). In particular, the volume of the breast lesion determines the incidence of metastasis to the inguinal lymph nodes (Morrow, 2016).

In human medicine, the proliferation of the process into other tissues and their damage, which usually accompanies an increase in the primary neoplasia lesion (Maslyakova et al., 2017), is accompanied by an increase in coagulation mechanisms, which is consistent with the results of our studies of haemostasis and biochemical markers in dogs with breast tumours. Based on the evaluation of hematological, biochemical and hemostatic disorders in breast tumors, Duda et al. (2017) have linked hyperfibrinogenemia and D-dimer elevation to the size and degree of neoplasia progression in a manner consistent with our findings. In this case, unlike the hyperproteinemia in dogs with breast neoplasia established by Lallo et al. (2016), we reported a decrease in total protein content. One of the reasons for the prolonged coagulation tests (duration of activated partial thromboplastin and prothrombin time) is probably the inflammatory response, as indicated by Bauer \& Moritz (2013).

That is, the course of the neoplasia process is characterized by an increase in the inhibitory potential of the blood in the case of disease progression with an increase in the size of the tumour foci, reflecting the course of the acute-phase reaction. In this case, malignancies show a deficiency of the $\alpha_{1}$-inhibitory potential of the blood due to the high level of proteolytic aggression of the tumour. At the same time, excessive production of $\alpha_{2}$-macroglobulin reflects the T-cell level of specific immunity. Despite some differences as to the importance of size as a prognostic factor in which the T-criterion changes, most studies confirm the usefulness of the classification system, given that tumour size is likely to be prognostic. The prognosis is likely to change gradually with increasing tumour size, but the modified system records significant changes in prognosis based solely on tumour size (Sorenmo et al., 2011), though this is important given that the disease progression occurs in $95 \%$ of cases (Marconato et al., 2009). Along with the histological type, clinical stage of TNM and tumour size remain important prognos- tic factors for breast cancer in dogs, but this issue needs further study to determine rational local and general conservative therapy as well as surgical boundaries (Philibert et al., 2003).

Thus, the results obtained by us are consistent with the general patterns of disorders of the hemostatic system and endothelial function in breast tumours and indicate their strengthening in case of increase in the size of neoplasia foci, which may indicate an increase in the aggressiveness of tumours. In our opinion, further research in this area is desirable, which is likely to determine the relationship between hemostatic balance and other factors that cause neoplasm malignancy.

\section{Conclusions}

In the course of the development of breast neoplasia in dogs, tumour cell metastasis, certain dynamics of the ratios of procoagulatory, anticoagulant mechanisms and the fibrinolysis system that underlie oncogenesis arise. Against the background of multiple vectors of changes in hemostatic signs for breast tumours in dogs, an increase in their magnitude is accompanied by a deepening of hypercoagulable state and disorders of endothelial function, activation of proteolysis and development of oxidative stress and endotoxemia, indicating the presence of direct correlation between the size and invasiveness of neoplasm.

Progression of disturbance of hemostatic balance in the case of increased neoplasia is mainly due to the excessive activation of the extrinsic blood coagulation pathway, which is triggered by a tissue factor, although there is also evidence of an increased imbalance of the internal coagulation mechanism associated with endothelial function.

Generalized results of clinical and experimental studies indicate that the system of clinical and morphological and hemostatic criteria allows one to assess the degree of aggressiveness of the tumour process, which is especially important at the stage of early pre-operative diagnosis and control of the effectiveness of treatment for neoplasia of the breast in female dogs.

\section{References}

Abdelmegeed, S. M., \& Mohammed, S. (2018). Canine mammary tumors as a model for human disease. Oncology Letters, 15(6), 8195-8205.

Adesanya, M. A., Maraveyas, A., \& Madden, L. A. (2016). PO-27 - thrombin generation in pancreatic cancer and multiple myeloma with use of calibrated automated thrombography. Thrombosis Research, 140(1), 186.

Al-Mansour, M. A., Kubba, M. A., Al-Azreg, S. A., \& Dribika, S. A. (2018). Comparative histopathology and immunohistochemistry of human and canine mammary tumors. Open Veterinary Journal, 8(3), 243-249.

Andreasen, E. B., Tranholm, M., Wiinberg, B., Markussen, B., \& Kristensen, A. T. (2012). Haemostatic alterations in a group of canine cancer patients are associated with cancer type and disease progression. Acta Veterinaria Scandinavica, 54,3 .

Andreeva, L. I., Kozhemjakin, L. A., \& Kishkun, A. A. (1988). Modifikacija metoda opredelenija perekisej lipidov v teste s tiobarbiturovoj kislotoj [Modification of the method for determination of lipid peroxides in the test with thiobarbituric acid]. Laboratornoe Delo, 11, 41-43 (in Russian).

Aresu, L., Giantin, M., Morello, E., Vascellari, M., Castagnaro, M., Lopparelli, R., Zancanella, V., Granato, A., Garbisa, S., Aricò, A., Bradaschia, A., Mutinelli, F., \& Dacasto, M. (2011). Matrix metalloproteinases and their inhibitors in canine mammary tumors. BMC Veterinary Research, 7, 33.

Ariyarathna, H., de Silva, N., Aberdein, D., Kodikara, D., Jayasinghe, M., Adikari, R., \& Munday, J. S. (2018). Clinicopathological diversity of canine mammary gland tumors in Sri Lanka: A one-year survey on cases presented to two veterinary practices. Veterinary Sciences, $5(2), 46$.

Astrup, T., \& Mullertz, S. (1952). The fibrin plate metod for estimating fibrinolitic activity. Archives of Biochemistry and Biophysics, 40, 346-351.

Bauer, N., \& Moritz, A. (2013). Characterisation of changes in the haemostasis system in dogs with thrombosis. Journal of Small Animal Practice, 54(3), $129-136$.

Belicer, V. O., Varec'ka, T. V., \& Veremjejenko, K. M. (1997). Kil'kisne vyznachennja fibrynogenu v plazmi krovi ljudyny [Quantitative determination of fibrinogen in human plasma]. Laboratorna Diagnostyka, 2, 53-55 (in Ukrainian).

Bely, D. D., Rublenko, M. V., Rublenko, S. V., Yevtushenko, I. D., Suslova, N. I., \& Samoyuluk, V. V. (2018). Pharmacological correction of the hemostasis system for the surgical treatment of bitches with tumours of the mammary gland. Regulatory Mechanisms in Biosystems, 9(3), 353-362. 
Benavente, M. A., Bianchi, C. P., \& Aba, M. A. (2016). Canine mammary tumors: Risk factors, prognosis and treatments. Journal of Veterinary Advances, 6(8), 1291-1300.

Burrai, G., Tanca, A., De Miglio, M., Abbondio, M., Pisanu, S., Polinas, M., Pirino, S., Mohammed, S., Uzzau, S., Addis, M., \& Antuofermo, E. (2015). Investigation of HER2 expression in canine mammary tumors by antibodybased, transcriptomic and mass spectrometry analysis: Is the dog a suitable animal model for human breast cancer? Tumor Biology, 36(11), 9083-9091.

Caine, G. J., Stonelake, P. S., Lip, G. Y., \& Kehoe, S. T. (2002). The hypercoagulable state of malignancy: Pathogenesis and current debate. Neoplasia, 4, 465-473.

Cassali, G. D., Bertagnolli, A. C., Ferreira, E., Damasceno, K. A., Gamba, C. O., \& Campos, C. B. (2012). Canine mammary mixed tumours. A review. Veterinary Medicine International, 2012, 7.

Cerovšek, M., Plavec, T., Zrimšek, P., Pogačnik, M., \& Zabavnik Piano, J. (2013). Clinicopathological survey of 56 canine malignant mammary tumours in Slovenia. Slovenian Veterinary Research, 50(3), 93-102.

Chang, S.-C., Chang, C.-C., Chang, T.-J., \& Wong, M.-L. (2005). Prognostic factors associated with survival two years after surgery in dogs with malignant mammary tumors: 79 cases (1998-2002). Journal of the American Veterinary Medical Association, 227(10), 1625-1629.

Chapin, J. C., \& Hajjar, K. A. (2015). Fibrinolysis and the control of blood coagulation. Blood Reviews, 29(1), 17-24.

Docampo, M. J., Cabrera, J., Rabanal, R. M., \& Bassols, A. (2011) Expression of matrix metalloproteinase- 2 and -9 and membrane-type 1 matrix metalloproteinase in melanocytic tumors of dogs and canine melanoma cell lines. American Journal of Veterinary Research, 72(8), 1087-1096.

Duda, N. C., Valle, S. F., Matheus, J. P., Angeli, N. C., Vieira, L. C., Oliveira, L. O., Sonne, L., \& González, F. H. (2017). Paraneoplastic hematological, biochemical, and hemostatic abnormalities in female dogs with mammary neoplasms. Pesquisa Veterinária Brasileira, 37(5), 479-484.

Falanga, A., Marchetti, M., \& Vignoli, A. (2013). Coagulation and cancer: Biological and clinical aspects. Journal of Thrombosis and Haemostasis, 11(2), 223-233.

Ferreira, E., Bertagnolli, A. C., Cavalcanti, M. F., Schmitt, F. C., \& Cassali, G. D. (2009). The relationship between tumour size and expression of prognostic markers in benign and malignant canine mammary tumours. Veterinary and Comparative Oncology, 7, 230-235.

Gerry, A. P., \& Malcolm, J. B. (2007). Clinical stage, therapy, and prognosis in canine anal sac gland carcinoma. Journal of Veterinary Internal Medicine, 21(2), 274-280.

Goldschmidt, M., Peña, L., Rasotto, R., \& Zappulli, V. (2011). Classification and grading of canine mammary tumors. Veterinary Pathology, 48(1), 117-131.

Golikov, P. P. (2004). Oksid azota v klinike neotlozhnyh zabolevanij [Nitric oxide in the clinic for urgent diseases]. Medpraktika, Moscow (in Russian).

Graf, C., \& Ruf, W. (2018). Tissue factor as a mediator of coagulation and signaling in cancer and chronic inflammation. Thrombosis Research, 164(1), 143-147.

Gruber, E. J., Catalfamo, J. L., \& Stokol, T. (2016). Role of tissue factor expression in thrombin generation by canine tumor cells. American Journal of Veterinary Research, 77(4), $404-412$.

Kaszak, I., Ruszczak, A., Kanafa, S., Kacprzak, K., Król, M., \& Jurka, P. (2018). Current biomarkers of canine mammary tumors. Acta Veterinaria Scandinavica, 60, 66 .

Kolodziejczyk-Czepas, J., Sieradzka, M., Moniuszko-Szajwaj, B., Pecio, Ł., Ponczek, M. B., Nowak, P., \& Stochmal, A. (2017). The role of fibrinogen, fibrin and fibrin(ogen) degradation products (FDPs) in tumor progression. International Journal of Biological Macromolecules, 99, 141-150.

Kristensen, A. T., Wiinberg, B., Jessen, L. R., Andreasen, E., \& Jensen, A. L. (2008). Evaluation of human recombinant tissue factor-activated thromboelastography in 49 dogs with neoplasia. Journal of Veterinary Internal Medicine, 22(1), 140-147.

Lallo, M. A., Ferrarias, T. M., Stravino, A., Juliana, F. M., Rodriguez, R., \& Zucare, L. C. (2016). Hematologic abnormalities in dogs bearing mammary tumors. Revista Brasileira de Ciência Veterinária, 23, 3-8.

Lima, L. G., \& Monteiro, R. Q. (2013). Activation of blood coagulation in cancer: Implications for tumour progression. Bioscience Reports, 33(5), 701-710.

Macotpet, A., Suksawat, F., Sukon, P., Pimpakdee, K., Pattarapanwichien, E., Tangrassameeprasert, R., \& Boonsiri, P. (2013). Oxidative stress in cancerbearing dogs assessed by measuring serum malondialdehyde. BMC Veterinary Research, 11,101 .
Marchetti, M., Diani, E, ten Cate, H., \& Falanga, A. (2012). Characterization of the thrombin generation potential of leukemic and solid tumor cells by calibrated automated thrombography. Haematologica, 97(8), 1173-1180.

Marconato, L., Romanelli, G., Stefanello, D., Giacoboni, C., Bonfanti, U., Bettini, G., Finotello, R., Verganti, S., Valenti, P., Ciaramella, L., \& Zini, E. (2009). Prognostic factors for dogs with mammary inflammatory carcinoma: 43 cases (2003-2008). Journal of the American Veterinary Medical Association, 235(8), 967-972.

Marschner, C. B., Wiinberg, B., Tarnow, I., Markussen, B., Kühnel, L., Bochsen, L., \& Kristensen, A. T. (2018). The influence of inflammation and hematocrit on clot strength in canine thromboelastographic hypercoagulability. Journal of Veterinary Emergency and Critical Care, 28(1), 20-30.

Morrow, M. (1996). Role of axillary dissection in breast cancer management. Annals of Surgical Oncology, 3(3), 233-234.

Orang, E., Marzony, E. T., \& Afsharfard, A. (2013). Predictive role of tumor size in breast cancer with axillary lymph node involvement - can size of primary tumor be used to omit an unnecessary axillary lymph node dissection? Asian Pacific Journal of Cancer Prevention, 14(2), 717-722.

Peña, L., Gama, A., Goldschmidt, M., Abadie, J., Benazzi, C., Castagnaro, M., Díez, L., Gärtner, F., Hellmén, E., Kiupel, M., Millán, Y., Miller, M., Nguyen, F., Poli, A., Sarli, G., Zappulli, V., \& de las Mulas, J. (2014). Canine mammary tumors: A review and consensus of standard guidelines on epithelial and myoepithelial phenotype markers, HER2, and hormone receptor assessment using immunohistochemistry. Veterinary Pathology, 51(1), 127-145.

Philibert, J. C., Snyder, P. W., Glickman, N., Glickman, L. T., Knapp, D. W., \& Waters, D. J. (2003). Influence of host factors on survival in dogs with malignant mammary gland tumors. Journal of Veterinary Internal Medicine, 17(1), 102-106.

Pollan, M., Pastor-Barriuso, R., Ardanaz, E., Argüelles, M., Martos, C., Galcerán, J., Sánchez-Pérez, M.-J., Chirlaque, M.-D., Larrañaga, N., Martínez-Cobo, R., Tobalina, M.-C., Vidal, E., Marcos-Gragera, R., Mateos, A., Garau, I., Rojas-Martín, M.-D., Jiménez, R., Torrella-Ramos, A., Perucha, J., Pérez-deRada, M.-E., González, S., Rabanaque, M.-J., Borràs, J., Navarro, C., Hernández, E., Izquierdo, Á., López-Abente, G., \& Martínez, C. (2009). Recent changes in breast cancer incidence in Spain, 1980-2004. Journal of the National Cancer Institute, 101, 1584-1591.

Quick, A. J. (1974). Hemmorragic disease and pathology of hemostasis. Springfield.

Ruf, W., Rothmeier, A., \& Graf, C. (2016). Targeting clotting proteins in cancer therapy - progress and challenges. Thrombosis Research, 140(1), 1-7.

Sierko, E., \& Wojtukiewicz, M. (2007). Inhibition of platelet function: Does it offer a chance of better cancer progression control? Journal of Thrombosis and Haemostasis, 33(7), 712-721.

Soares, N. P., Medeiros, A. A., Castro, I. P., Wilson, T. M., Moreira, T. A., \& Andrade, M. B. (2017). Prognostic factors in canine mammary carcinomas and HER2 expression relationship. Acta Scientiae Veterinariae, 45, 1443.

Sorenmo, K. U., Rasotto, R., Zappulli, V., \& Goldschmidt, M. H. (2011). Development, anatomy, histology, lymphatic drainage, clinical features, and cell differentiation markers of canine mammary gland neoplasms. Veterinary $\mathrm{Pa}$ thology, 48(1), 85-97.

Stockhaus, C., Kohn, B., Rudolph, R., Brunnberg, L., \& Giger, U. (1999). Correlation of haemostatic abnormalities with tumour stage and characteristics in dogs with mammary carcinoma. Journal of Small Animal Practice, 40, 326-331.

Vareckaja, T. V., Mihajlovskaja, L. I., \& Svital'skaja, L. A. (1992). Opredelenie rastvorimogo fibrina $\mathrm{v}$ plazme krovi [Determination of soluble fibrin in blood plasma]. Klinicheskaja Laboratornaja Diagnostika, 7-8, 10-14 (in Russian).

Veremeenko, K. N., Volohonskaja, L. I., \& Kizim, A. I. (1978). Metody opredelenija prekallikrein-kallikreinovoj sistemy v krovi cheloveka [Methods for the determination of prekallikrein-kallikrein system in human blood]. Kyiv (in Russian).

Vilar Saavedra, P., Lara García, A., Zaldívar López, S., \& Couto, G. (2011) Hemostatic abnormalities in dogs with carcinoma: A thromboelastographic characterization of hypercoagulability. Veterinary Journal, 190(2), 78-83.

Wojtukiewicz, M. Z., Sierko, E., Klement, P., \& Rak, J. (2001). The hemostatic system and angiogenesis in malignancy. Neoplasia, 3(5), 371-384.

Wojtukiewicz, M., Sierko, E., \& Rak, J. (2004). Contribution of the hemostatic system to angiogenesis in cancer. Seminars in Thrombosis and Hemostasis, 30(1), 5-20.

Yamagami, T., Kobayashi, T., Takahashi, K., \& Sugiyama, M. (1996). Prognosis for canine malignant mammary tumors based on TNM and histologic classification. Journal of Veterinary Medical Science, 58(11), 1079-1083. 